Toespraak gelewer by 'n vergadering van die Pretoriase tak van die Suid-Afrikaanse Verpleegstersvereniging gedurende April 1980.

\title{
DIE GETROUDE VROU IN DIE VERPLEEGBEROEP
}

"Wat is die eise wat die Verpleegberoep aan die Getroude vrou stel en hoe voldoen sy daaraan?',

Kitty van Niekerk, Lektrise, Universiteit van Suid-Afrika.

$\mathbf{O}$ $m$ enigsins reg te laat geskied aan 'n omvattende onderwerp soos "die getroude vrou in die verpleegberoep" moet van naderby gekyk word na die volgende:

1. Waarom getroude vroue in die verpleegberoep as 'n groep van belang beskou word.

2. Die eise wat die gesin aan die vrou stel.

3. Die eise wat die vrou aan haarself stel.

4. Die eise wat die beroep aan die getroude verpleegkundige stel.

5. Die eise wat die getroude verpleegkundige aan die beroep stel.

6. Verantwoordbare voorstelle wat mag help om te voldoen aan sommige van die getroude vrou en die werkgewer se eise.

Getroude vroue vorm 'n belangrike groep in die verpleegberoep

Volgens die 1975 Onderwys- en Diensverslag van die Suid-Afrikaanse Verpleegstersvereniging was $62 \%$ van die praktiserende vroue wat volopbetaalde en volle lede van die verpleegberoep was, getroude vroue. (4p19). Dit beteken dat daar 19719 getroude en 11992 ongetroude vroue in die kategorie was - dus 7727 meer getroudes as ongetroudes.

Volgens jonger syfers verkrygbaar van die Verpleegstersvereniging het 'n opname gedurende 1976 aangetoon dat $50,25 \%$ van geregistreerde personeel in diens van die Provinsie en Departement Gesondheid getroud is en $56,9 \%$ van geregistreerdes in 'n monster van privaat en gesubsidieerde hospitaalposte, getroud is. Getroudes maak gemiddeld dus $51,3 \%$ van die verpleegtaakmag wat betrekkings beklee, uit. (5p24).

' $n$ Opname deur my en ' $n$ kollega het aangetoon dat tot $70 \%$ van geregistreerde verpleegkundiges in die betrokke diens getroud is. In die geval was daar dus NET 3 uit elke 10 geregistreerde verpleegkundiges ongetroud. (1).

$\mathrm{Na}$ my mening is dit 'n baie gesonde toestand daar dit wys op die goeie smaak en gesonde verstand van die manlike geslag in Suid-Afrika en dit wys dat verpleegkundiges se onderwys hulle "breed" voorberei het om ook hul plek in die samelewing te kan volstaan!

Afgesien van die belangrike getalle wat getroude verpleegkundiges as 'n aparte "groep" kategoriseer is daar ook die volgende redes vir die groepsafbakening: - groepslede ondervind gemeenskaplike probleme
- redes waarom persone tot die groep toetree is dikwels eenders of ten minste soortgelyk

- die werkgewer veralgemeen probleme wat met individuele lede ondervind word tot groepsprobleme. Die individu word getipeer as "nog een van daardie werkende vrouens/moeders". Die tipering word ongelukkig dikwels smalend en neerhalend aangehaal

- daar bestaan 'n gevoel van simpatie en begrip, 'n "ons"-gevoel tussen groepslede.

\section{Die eise van die gesin}

Werkende getroude verpleegkundiges se ouderdomme wissel van 18 tot 70 jaar. Hierdie feit dui aan dat daar behalwe die ooreenkomste ook groot verskille tussen groepslede is. Met verwysing na Steyn en Breedt se siening in "Die Veranderende Gesin" kan daar gepraat word van 'n "lewensiklus" (3p170) van die gesin. Die siklus verskil is individuele gesinne omdat die gesin in verskillende ouderdomstadia of ouderdomsfases kan wees. Die siklus mag binne die ouderdomsfases ook verskil omdat die samelewingstruktuur en die maatskaplike milieu waarin die gesin gesitueer is ' $n$ invloed op die wese van die gesin uitoefen.

Met betrekking tot die getroude vrou in die verpleegberoep is dit belangrik om die fase waarin die besondere vrou se gesin verkeer, te ken en te verstaan. Dit is ook belangrik om te besef dat ' $n$ gesin gelyktydig in twee of meer fases kan verkeer.

Die eise wat in elke fase aan die getroude vrou gestel word, is veelvuldig en vir die doeleindes van hierdie bespreking sal net daardie eise wat eerstens die getroude vrou tot die beroepslewe laat toetree en ten tweede konflik veroorsaak wanneer sy werk, geïdentifiseer word.

\section{FASE 1: Die pasgetroude, eerste swangerskapfase}

Die belangrikste eise tydens hierdie fase het te doen met TYD en GELD.

Tyd om:

- mekaar beter te leer ken

- nuwe rolle aan te leer

- tot vergelyk te kom oor elkeen se take en pligte

- 'n bevredigende seksuele verhouding daar te stel

- doeltreffend te kommunikeer op emosionele en intellektuele vlak 
- gesonde verhoudings met skoonfamilie te ontplooi.

Geld om:

- behuising / ameublement/gewone lewensmiddele en vervoer te bekom

- te voorsien vir toekomstige kinders en periodes waarin die vrou glad nie tot die inkomste sal kan bydra nie.

Ander vereistes mag te doen hê met die behoefte aan selfaktualisering en die fisiese/psigiese aanpassings wat tydens 'n eerste swangerskap gemaak moet word en verdere aanpassings van min slaap en baie verantwoordelikheid wanneer die geidealiseerde nuweling arriveer.

FASE 2: Die fase waarin daar een of meer voorskoolse kinders in die gesin is

TYD is nodig vir aandag aan en opvoeding van elke individuele kind, en om manlief gelukkig te hou. Meer tyd word deur kinders met kindersiektes en minder ernstige toestande soos mangelontsteking in beslag geneem. Huislike pligte vermeerder.

Uitgawes verhoog ooreenkomstig.

Die vrou is dikwels moeg en een van my vriendinne het met die volgende rympie gesê hoe moeg:

\section{"Weep not for me, friends, \\ Though death do us sever. \\ I am going to do nothing \\ For ever and ever".}

(2p71).

\section{FASE 3: 'n Gesin met kinders op die laerskool}

Finansiële eise stapel op: tasse, skoolklere, uitstappies, konserte, voedsel, mediese koste, musieklesse, sport, voortrekkers. 'n Groter huis in 'n "goeie" voorstad is nodig ter wille van "goeie" maats, "goeie" skole, ruimte vir elke kind.

TYD is kosbaar - die skool verwag 'n bydrae met toesig en vervoer van kinders na en van buitebedrywighede. Dit vererger die tydsprobleem.

FASE 4: Ouers versus tienderjarige en adolessente Emosionele spanning en konflik - 'n generasiegaping. Ouers moet nou vriende/kamerade wees. Dogters benodig skoonheidsmiddels, seuns wil meisies “uitneem", en albei geslagte wil soos hul portuurgroep gekleed gaan, tot elke prys.

Partytjies, plate, fietse, skooltoere, vakansietoere.

TYD en GELD!

\section{FASE 5: Die sogenaamde leë-nes stadium}

Uitgawes bly konstant, inkomstebelasting verhoog, ouers voel geïsoleerd. Siekte van man of vrou mag voorkom.

Tydens al hierdie fases waarin die getroude vrou twyfel of sy geld of tyd moet kies, is daar ook nog dieperliggende behoeftes by die vrou naamlik om

- vir haar medemens van waarde te wees

- in voeling met haar beroep te bly
- die "sleurwerk" van huisvrou-wees tydelik of periodiek te ontduik

- "ekstras", bv, vrieskas, wasmasjien, nuwe motor aan te koop

- "sakgeld" te verdien omdat sy dit moeilik vind om haar man te vra

- kinders die geleentheid te bied om hulle potensiaal te verwerklik deur bv. musiek te neem

- haar man te help om verder te studeer

- kommunikasie met mense wat soos sy voel en dink te hê. Verpleegkundiges vind dikwels hul tydgenote oppervlakkig

- vreemdheid in 'n nuwe omgewing te oorbrug deur kontak met nuwe potensiële vriende te maak.

Indien die vrou nou gaan werk, ontstaan daar onmiddellik 'n probleem van TYD en 'n probleem met betrekking tot die rolverwagtings wat die besondere gemeenskap, die familie en skoonouers van die man en vrou koester.

Rolle binne die gesin moet heroorweeg en pligte hertoegesê word.

Wrywing kan in die gesin ontstaan.

Wedersydse ondersteuning van die egpaar teenoor mekaar en ondersteuning en begrip in die familie is nou van kernbelang.

Probleme soos

- beperkte sosiale verkeer

- verbrokkeling van vriendskappe en familiebande hou verband met die gebrek aan TYD.

Alhoewel nuwe vriendskappe in die werksituasie gesluit word, is dit dikwels nie "gesinsvriendskappe" nie. Hegter gesinsbande moet dus vergoed vir die leemte.

\section{Die eise wat die vrou aan haarself stel}

Alhoewel ek dit nie kan bewys nie, wil ek beweer dat die vrou wat gevra word wat sy van haarself verwag in haar driedubbele rol: vrou, moeder, verpleegkundige, sal antwoord dat sy graag aldrie rolle baie goed wil vervul. Die meeste van die persoonlike probleme van die getroude verpleegkundige spruit dan ook hieruit.

Opsommenderwys kan hierdie probleme die volgende insluit:

- skuldgevoelens teenoor man en/of kinders

- fisiese/emosionele onvermoë om die huis en die werk se verpligtinge volgens haar eie hoë standaarde na te kom. Dit mag tot prikkelbaarheid en 'n gevoel van magteloosheid lei.

- twyfel oor die prioriteitsvolgorde van haar verantwoordelikhede

- gebrek aan tyd om haarself te versorg. Sy verval in groef: kombuis - kinders - kerk - werk

- bekommernis oor die plasing/versorging van $\mathrm{baba} /$ peuter/kleuter

- spanning oor siek kinders en wisseling van gewone reëlings (vervanging van sorg)

- onsekerheid oor hantering van kritiek van familielede/vriende

- onvermoë om aan eise van institusies, bv. skool (koekverkopings, sport) en kerk en van haar eggenoot (werks- en sosiale verpligtinge) te voldoen

- eie gesondheidsprobleme

- gebrek aan vryetyd met inkorting of afskaffing van bv. sportaktiwiteite, deelname aan musiek- of verenigings. 


\section{Die eise wat die beroep aan die vrou stel}

Die verpleegberoep bestaan vir die welsyn van die publiek. Uit hierdie oogpunt word dan van alle verpleegkundiges

- fisiese en emosionele inset

- geestelike paraatheid

- die jongste/nuutste kennis en vaardighede en

- 'n bydrae tot die uitbouing van hul professie verwag.

Om aan die eise te voldoen moet kwaliteitdiens gelewer word, en moet meegedoen word aan indiensopleiding, voortgesette onderwys soos selfgeïnisieerde leesprogramme, Verpleegstersverenigingtakvergaderings, kliniese onderrig moet beplan en evalueer word en die persoon moet gewillig wees om oortyd te onderneem wanneer dit ook al nodig blyk.

Bo en behalwe hierdie verantwoordelikheid word verwag dat die verpleegkundige aan konserte en prysuitdelings sal deelneem; sy moet vir die basaar werk; sy moet koek vir koekverkopings bydra; sy moet kliniese praktikatoetse en gevallestudies evalueer; sy moet elke volgende dag se administrasie- en onderrigprogram beplan; sy moet gewillig wees om te eniger tyd en op kort kennisgewing van sk of te verwissel.

\section{Die eise wat die vrou aan die beroep stel}

Volgens my siening het die getroude vrou tot dusver nog nooit daaraan gedink om eise aan die beroep te stel nie. Sy wil net graag haar medemens dien (dit is deel van die filosofie wat ons by verpleegkundiges inskerp), haar gesinslewe en -status verbeter en self iemand wees. Verpleegkundiges het nog net eise as ongeformuleerde begeertes gestel. Aspekte waaroor gekla word sluit in:

- kort kennisgewing van diensure vir die volgende week of van wisselings van skofte

- die moeilike ure waarop sy aan diens moet gaan

- geld

- diskriminasie by bevordering van die getroude teenoor die ongetroude

- die feit dat daar nie meer deeltydse werk beskikbaar is nie

- onsimpatieke houdings wanneer sy genoodsaak word om bv. by siek kinders te bly en geen alternatiewe reëlings getref kan word

- gebrek aan erkenning dat sy bydra tot pasiëntesorg Beskuldigings teen haar behels dat sy nie genoeg deelneem aan:

- voortgesette onderwys, indiensopleiding en takvergaderings; dat sy vergeet om dit duidelik te stel dat haar rede daarvoor nie belangeloosheid is nie.

Miskien is dit nou tyd dat die getroude vrou (tot soveel as 7 uit 10 van alle geregistreerde personeel in 'n diens) besef dat daar ' $n$ bedingingsmoontlikheid bestaan. Positiewe voorstelle in plaas van negatiewe klagtes sal alreeds vir meer werkstevredenheid sorg. Werkstevredenheid sal tot gehaltepasiëntesorg lei - 'n positiewe kringloop teenoor 'n negatiewe heksesirkel.

\section{Verantwoordbare voorstelle ter oplossing van sommige probleme}

Vir sommige, soos ek, mag die volgende raad iets beteken:
1. Reël met u moeder, 'n suster, u vriendin, sodat u een maal per jaar vir 'n naweek saam met u man alleen weggaan. Gaan een keer per maand alleen met u man uit, bv. na 'n restaurant.

2. Hou vol met ten minste een buite-aktiwiteit wat niks met verpleging te doen het nie. Wat van drama of kookkuns of houtsneewerk, of iets waaraan u saam met u man en kinders deelneem, bv draf?

3. Bring 'n spesiale tydjie met elke kind allenig deur elke week. Die kind moet weet dat dit sy/haar spesiale tyd is.

4. Bespreek die redes waarom $u$ werk openlik met $u$ kinders en laat hulle besluit of dit vir u almal noodsaaklik is dat u werk. Maak dus u sommetjies van die voor- en nadele van u werk saam met hulle.

5. Hou 'n klagtekassie waarin kinders briefies kan laat oor probleme wat opduik wanneer u nie tuis is nie en los dit op sodra u kan.

6. Kyk na uself en sorg dat u mooi, netjies en gesond bly.

7. Woon die takvergaderings by en bring u kind/u man saam.

8. Moet nie vir onnodige/selfsugtige redes, bv. luukse skoonheidsmiddels, werk nie. In u besprekingsessie met u kinders sal u wel gou kan oordeel of u fouteer.

9. Moet nie toelaat dat iemand kan sê u werk net vir geld nie. Moet nooit self so sê nie want dit word as 'n aantyging teen al u getroude kollegas gebruik en dit is gewoonlik net 'n oppervlakkige, ontvlugtingsantwoord

10. Moet nie u man gebruik om uit moeilike situasies te kom nie, bv. as u nie kans sien vir nagdiens nie, te sê: "'my man weier dat ek nagdiens doen". Ek weet dat die meeste mans net weier as hul vrouens hul dit in die mond gelê het. Dit belemmer die getroude vrou se posisie.

Voorstelle vir oorweging deur die owerheid wat die hoogste gehalte dienslewering van hul werknemers verwag, is:

1. Die instelling van 'n voorligtingsdiens vir getroude gesondheidsdienspersoneel. Onthou sy/haar probleme is uniek. Spesiale persoonlikheids- en onderwyskwalifikasies is nodig vir so 'n voorligter.

2. Dat 'n lys name en adresse beskikbaar gestel moet word sodat bv. tuishulp, baba-oppassers, naskoolse versorgingsentrums, maklik bekom kan word. Dit is veral belangrik vir nuwe inwoners in die stad.

3. Oriënteer alle verpleegkundiges by hertoetrede tot die beroep (bv. 2 weke indienskursus). Tyd word gemors en persone voel ongelukkig as hulle moet rondval en uitvis wat van hulle verwag word.

4. Maak gebruik van skiktyd en/of spesiale skofte. Ek ken 'n persoon wat al 16 jaar by een plek werk. Haar skof is $6 \mathrm{~h} 00$ tot $11 \mathrm{~h} 00$. 'n Ander hospitaal het 'n middagsk of $14 \mathrm{~h} 30$ tot 20h30. Daar is altyd 'n waglys van persone vir hierdie pos. Vir 'n moeder 
beteken dit 'n 36 uur werksweek maar haar kind is net sonder haar van 14 h 30 tot 16 h30 - dan is manlief tuis.

5. Dat aandiensure maandeliks of selfs driemaandeliks vooruit bekend moet wees. Hierdie voorstel impliseer natuurlik dat tussensaalwisselings van geregistreerde personeel sover moontlik beperk moet word.

6. Stel noodversorgingsgeriewe vir personeel se kinders beskikbaar, bv. 'n 'siekeboeg' en oornagfasiliteite. Enige huishouding vind dat vergaderings ens. dikwels mens se normale reelings ontwrig en $\mathrm{u}$ werknemer is gelukkig as haar kinders veilig is.

7. Dat daar kennis geneem sal word van die gesinsomstandighede van elke verpleegkundige. Hiervoor is navorsing nodig om probleme wat in elke fase van die gesin voorkom, af te baken sodat voorligting verbeter kan word. Die inligting moet jaarliks bygehou word.

8. Dit sou wonderlik wees as twee getroude vroue in verskillende gesinsfases altyd in 'n skaduposisie teenoor mekaar kan werk - as A nie kan kom nie, reël sy met $\mathbf{B}$. Die saal is altyd gedek en die pasiënt sal tevrede wees. Dié twee vroue sal sien dat elkeen sy nodige 40 uur of wat ook al, werk.
Vir toekomstige werwing sal dit goed wees om te onthou dat 'n nuwe publikasie "Woman at Work" deur Jenny Glew sê dat "vroue"'-werk swak betaald is en sy propageer dat gematrikuleerde vroue liewer beroepe soos ingenieurswese en ander hoog betaalde beroepe wat deeltyds beoefen kan word. moet kies. Wat sal van verpleging word sonder die $50 \%$ getroude personeel?

\section{SLOT}

Ek het my kinders gevra of ek moet sê hoe swaar húlle gekry het omdat ek my geregistreerde lewe lank 'n werkende moeder was. Die jongste (nou in standerd ses) sê toe: "maar Ma was altyd hier as dit nódig was." Dit is my beloning vir die taak wat aan my opgedra is vir vanaand!

\footnotetext{
BIBLIOGRAFIE

Ongepubliseerde Verslag oor die samestelling van 'n hospitaal se verpleegpersoneel. Readers Digest: Ripley's: Believe it or not. Volume 115, No. 692, December 1979. Steyn, A. F. en A. Breedt: Die Veranderende Gesin, Academica, Pretoria, 1977. Suid-Afrikaanse Verpleegsteersvereniging: Verslag oor Verpleegdiens in die Republiek van Suid-Afrika en die gebied van Suidwes-Afrika. S.A.V.V., Pretoria, 1975.

Suid-Afrikaanse Verpleegstersvereniging: Verslag oor Verpleegdiens in die Republiek van Suid-Afrika en Selfregerende Gebiede. S.A.V.Y., Pretoria, 1978.
} 